Egypt. J. of Nutrition and Health Vol. 15 No. 1 January (2020)

\title{
Protective effects of barley and wheat grasses on nephrotoxicity in rats and some biochemical parameters induced by tramadol
}

\author{
Hanan Salah Eldeen Eldamaty \\ Lecturer of Nutrition and Food Science, Nutrition and Food Sciences Dept., Faculty \\ of Home Economics, Al-Azhar University, Egypt
}

\begin{abstract}
The present study was conducted to evaluate the protective effects of barley and wheat grasses against tramadol induced nephrotoxicity, biochemical changes as well as oxidative stress in adult male albino rats. A total of thirty male albino rats $(150-200 \mathrm{~g})$ were divided into two main groups , The first main group was fed on basal diet and administrated distilled water orally for 30 days and kept as normal (-ve) control. The second main group was fed on basal diet and administrated tramadol $(30 \mathrm{mg} / \mathrm{kg} /$ day $)$ orally for 30 days to induce nephrotoxicity in male rats. After that, the rats in the second main group (25 rats ) were divided into five subgroups (each group consisted of 5 rats). Sub1; received tramadol and kept as tramadol group, Sub2; received tramadol + barley grass $(250 \mathrm{mg} / \mathrm{kg} /$ day $)$, Sub3; received tramadol + barley grass $(500 \mathrm{mg} / \mathrm{kg} /$ day $)$, Sub4; received tramadol + wheat grass $(250 \mathrm{mg} / \mathrm{kg} /$ day $)$ and Sub5; received tramadol + wheat grass $(500 \mathrm{mg} / \mathrm{kg} /$ day) orally for 30 days. Biological evaluation including $\mathrm{FI}, \mathrm{BWG} \%$ and FER was carried. (Relative kidneys weight were calculated). Serum was taken out from blood and assessed for creatinine, urea, uric acid, total protein, albumin, globulin, malondialdehyde (MDA), nitric oxide (NO), catalase (CAT) and glutathione peroxidase (GPX). Kidneys were removed, weighed and also evaluated for malondialdehyde (MDA), nitric oxide (NO), catalase (CAT) and reduced glutathione (GSH) in its tissues. In conclusion, the study showed that administration of barley and wheat grasses at high doses $(500 \mathrm{mg} / \mathrm{kg} / \mathrm{day})$ with tramadol improved the nephrotoxicity, the biochemical changes and antioxidant enzymes in both of serum and kidneys tissues might be due to the possible antioxidant content.
\end{abstract}

Key words: nephrotoxicity, serum biochemical parameters, kidneys tissues antioxidant enzymes, barley grass, wheat grass.

\section{Introduction}

Tramadol a substitute artificial opioid anesthetic, which is used to treat modest or severe pain (Pinho et al. 2013). Tramadol after being absorbed, it reached to the liver, after circulation in the blood, it is extracted by the kidneys. Therefore, these organs are reflect tramadol toxicity (Barbosa et al. 2017). Tramadol was discovered and manufactured in 1962 for the first time by German company (Grunenthal $\mathrm{GmbH}$ ) for the cure of pain while being announced in the market by the name 'Tramadol' in 1977 (Patterson, 2018). Unfortunatry, it was abused and accompanied by worrying phenomenon among Egyptian public ( $\boldsymbol{A}$ hmed et al., 2018). Tramadol induced nephrotoxic effects by affecting renal function and oxidative stress (Haytham et al., 2020).

Barley grass reduced serum urea and creatinine and reduced kidney damage which happened as a result of high dose of gentamicin (Comba et al., 2017). Barley reduced chronic 


\section{Hanan Salah Eldeen Eldamaty}

kidney disease, through $\beta$-glucans which caused reduction of toxin blood levels as uremic toxin present in end-stage of renal disease (Cosola et al., 2017). Barley grass has detoxifying and antioxidant effects. It is rich in antioxidant compounds, such as flavonoids, polyphenols, superoxide dismutase (SOD), saponarin, lutonarin, Se, tryptophan, chlorophyll, vitamins (pro vitamin A, C, and E), dietary fiber (Zeng et al., 2018). Barley plays a main role in health. Zeng et al., (2020) reported that barley grass has antioxidant activity as flavonoids, SOD, vitamins, and dietary fiber as $\beta$-glucans.

Sachin et al., (2013) reported that wheat grass (Triticum aestivum) has antioxidants, and can be used as an phytomedicine against oxidative stress caused by chemotherapeutic drugs. Wheatgrass juice cleanses the toxins from the body, by many enzymes, and amino acids that play an essential role as a natural cleanser (Sareen et al. 2014). According to, Chauhan, (2014) wheat grass contains numerous antioxidant vitamins such as carotene, C, E, chlorophyll, antioxidant enzymes such as SOD, cytochrome oxidase and other enzymes. Administration wheat grass juice regularly has the ability to cure the problems of kidneys stone, inflammation, urinary bladder and reduce uric acid in the blood ( Neethu et al., 2016).Wheatgrass juice (WGJ) contains a high concentration of vitamin C and a lot of ingredients potent to join the liver with the kidneys for detoxification (Hesham et al., 2020).

The aim of this study was designed to find the potential effects of barley and wheat grasses due to their antioxidant abilities against tramadol induced nephrotoxicity in male rats.

\section{Materials and Methods}

\section{Materials:}

Plants:

The barley and wheat grains were purchased from Sakha Research Center ( Kafr Elsheikh, Egypt) .

\section{Chemicals:}

Tramadol tablets, each contains $225 \mathrm{mg}$ tramadol hydrochloride obtained from October Pharma Company(Giza, Egypt).

\section{Animals:}

Thirty male albino rats of Sprague Dawley strain, with a weight ranged from 150 to $200 \mathrm{~g}$ were obtained from the experimental animal house in Food Technology Research Institute, Agric. Res. Center, Giza, Egypt.

Methods:

Procedure of growing grasses:

Barley and wheat grains were soaked overnight in water to cultivate in a container. They were spread on the surface of the soil filled in plastic dishes. Grains were grown under indoor conditions. After the ninth day grasses were harvested and chopped with knife. It was dried in shade and powdered with a mechanical grinder. The powder was passed through sieve no.40 and stored in a labeled airtight container for study (Jain and Argal, 2014 and Malla et al., 2014).

\section{Dose of tramadol and grasses :}

Rats received tramadol at dose (30 mg/kg/day), orally for 30 days. This dose is $1 / 10$ of LD50. LD 50 is $\mathbf{2 8 6}-300 \mathrm{mg} / \mathrm{kg}$ (Elkhateeb et al., 2015). Rats received barley and wheat grasses at doses 


\section{Egypt. J. of Nutrition and Health Vol. 15 No. 1 January (2020)}

(250, $500 \mathrm{mg} / \mathrm{kg} /$ day). This doses were freshly prepared, suspended in distilled water and taken orally for 30 days ( Abed et al., 2017).

Experimental Design

Thirty rats were randomly divided into two main groups as follow:

The first main group ( 5 rats)

This group was fed on basal diet and administrated distilled water orally for 30 days and kept as normal control (-ve control).

\section{The second main group ( 25 rats)}

This group was fed on basal diet and administrated tramadol $(30 \mathrm{mg} / \mathrm{kg} / \mathrm{day})$ orally for 30 days to induce nephrotoxicity in male rats. After that, the rats in the second main group (25 rats) were divided into five subgroups (each group consisted of 5 rats) as follows:-

Subgroup 1: administrated tramadol (30mg/kg/day) and Kept as tramadol group (+ ve control)

Subgroup 2: administrated tramadol $(30 \mathrm{mg} / \mathrm{kg} /$ day $)+$ barley grass $(250 \mathrm{mg} / \mathrm{kg} /$ day $)$

Subgroup 3: administrated tramadol $(30 \mathrm{mg} / \mathrm{kg} /$ day $)+$ barley grass $(500 \mathrm{mg} / \mathrm{kg} / \mathrm{day})$

Subgroup 4: administrated tramadol (30 mg/kg/day) + wheat grass $(250 \mathrm{mg} / \mathrm{kg} /$ day $)$

Subgroup 5: administrated tramadol $(30 \mathrm{mg} / \mathrm{kg} /$ day $)+$ barley grass $(500 \mathrm{mg} / \mathrm{kg} /$ day $)$

Biological evaluation

Body weight and food consumption were measured twice a week and total food intake of the experimental period (30 days) was calculated according to Chapman et al., (1959) as follow: Body weight gain percent $(B W G \%)=$ Final body weight - Initial body weight / Initial body weight $x 100$. The feed efficiency ratio was calculated according to Hosoya, (1980) as follow: FER =Body weight gain (g) / total feed intake $(\mathrm{g})$.

\section{Relative kidney weight}

Relative kidney weight was calculated according to Adikwu and Bonsome, (2017) as follow: Relative kidney weight $=$ Absolute kidney weight $(\mathrm{g}) /$ Body weight at sacrifice $(\mathrm{g}) \times 100$.

\section{Kidney functions parameters}

Serum creatinine, serum urea and serum uric acid were determined according to (Murray and Kaplan, 1984; Kaplan, 1984 and Fossati et al., 1980).

\section{Serum protein parameters:}

Total protein was estimated according to the method of Bowers and Wong (1980), albumin and globulin were estimated according to the method of (Doumas et al. 1977).

\section{Antioxidant enzymes in serum}

Malondialdehyde ( MDA), Nitric oxide ( No), Catalase ( CAT), and Glutathione peroxidase (GPx) were determined in serum acoording to th methods of (Ruiz-Larrea et al.,1994; Moshage et al .,1995; Goth et al., 1984 and Ahmadvand et al., 2014).

\section{Antioxidant enzymes in kidneys tisues}

Malondialdehyde ( MDA), Nitric oxide ( No), Catalase ( CAT), and reduced glutathione (GSH) were determined in kidneys tissues according to the methods of (Placer et al., 1966; Green et al., 1982; Aebi, 1974 and Maral et al., 1977).

\section{Statistical analysis}

Statistical analysis was carried out using one way analysis of variance(ANOVA) test followed by Duncan test through the programme of statistical packages for the social science (SPSS) version 


\section{Hanan Salah Eldeen Eldamaty}

16. Results were expressed as mean \pm SD. The differences among means at $p<0.05$ are considered significant (George et al., 1989).

\section{Results}

\section{Biological evaluation:}

Results of feed intake (FI), body weight gain \% (BWG) and feed efficiency ratio (FER) were shown in (table 1). There is significant decrease of these parameters in tramadol group compared to normal control. On the other hand, there were significant increase in the other groups when compared with tramadol group. Regarding to $\mathrm{Fl}$, there were no significant differences among all grasses groups and normal control. The best results for BWG were recorded for wheat grass powder $(500 \mathrm{mg} / \mathrm{Kg})$ and barley grass powder $(500 \mathrm{mg} / \mathrm{Kg})$, while group of wheat grass powder $(250 \mathrm{mg} / \mathrm{Kg})$ was the best result for FER.

Table ( 1 ) :

Effects of Barley grass (BG) and Wheat grass (WG) powder on feed intake, body weight gain and feed efficiency ratio in rats (mean $\pm S D)$.

\begin{tabular}{l|c|c|c}
\hline \multicolumn{1}{c|}{ Groups } & FI $(\mathrm{g})$ & BWG $(\%)$ & FER \\
\hline Normal control & $18.9 . \pm 0.23^{\mathrm{a}}$ & $30.71 \pm 4.02^{\mathrm{a}}$ & $0.16 \pm 0.02^{\mathrm{a}}$ \\
\hline Tramadol $30 \mathrm{mg} / \mathrm{kg} / \mathrm{d}$ & $17.13 \pm 0.56^{\mathrm{b}}$ & $22.00 \pm 3.68^{\mathrm{e}}$ & $0.05 \pm 0.02^{\mathrm{e}}$ \\
\hline Tramadol + BG(250mg/kg/d) & $0.19^{\mathrm{a}} \pm 18.9$ & $22.57 \pm 1.23^{\mathrm{e}}$ & $0.08 \pm 0.01^{\mathrm{c}}$ \\
\hline Tramadol + BG $(500 \mathrm{mg} / \mathrm{kg} / \mathrm{d})$ & $0.24^{\mathrm{a}} \pm 19.02$ & $25.43 \pm 2.20^{\mathrm{c}}$ & $0.07 \pm 0.01^{\mathrm{d}}$ \\
\hline Tramadol + WG $(250 \mathrm{mg} / \mathrm{Kg} / \mathrm{d})$ & $0.15^{\mathrm{a}} \pm 19.26$ & $24.38 \pm 4.53^{\mathrm{d}}$ & $0.12 \pm 0.02^{\mathrm{b}}$ \\
\hline Tramadol + WG $(500 \mathrm{mg} / \mathrm{kg} / \mathrm{d})$ & $0.25^{\mathrm{a}} \pm 19.22$ & $28.21 \pm 5.98^{\mathrm{ab}}$ & $0.09 \pm 0.02^{\mathrm{C}}$ \\
\hline
\end{tabular}

Means in the same column with completely different letters are significantly different at $p<0.05$.

\section{Relative kidney weight :}

The results of relative kidney weights were not significantly altered in tramadol group when compared to normal control and other groups (table 2).

Table ( 2 ):

Effects of Barley grass (BG) and Wheat grass (WG) powder on relative kidney weight in rats (mean $\pm \mathrm{SD}$ ).

\begin{tabular}{l|c}
\hline \multicolumn{1}{c|}{ Groups } & Relative kidney weight \\
\hline Normal control & $0.50 \pm 0.07^{\mathrm{a}}$ \\
\hline Tramadol $30 \mathrm{mg} / \mathrm{kg} / \mathrm{d}$ & $0.52 \pm 0.12^{\mathrm{a}}$ \\
\hline Tramadol + BG $(250 \mathrm{mg} / \mathrm{kg} / \mathrm{d})$ & $0.54 \pm 0.19^{\mathrm{a}}$ \\
\hline Tramadol + BG $(500 \mathrm{mg} / \mathrm{kg} / \mathrm{d})$ & $0.51 \pm 0.05^{\mathrm{a}}$ \\
\hline Tramadol + WG $(250 \mathrm{mg} / \mathrm{Kg} / \mathrm{d})$ & $0.51 \pm 0.09^{\mathrm{a}}$ \\
\hline Tramadol + WG $(500 \mathrm{mg} / \mathrm{kg} / \mathrm{d})$ & $0.53 \pm 0.04^{\mathrm{a}}$ \\
\hline
\end{tabular}

Means in the same column with completely different letters are significantly different at $\mathrm{p}<0.05$.

\section{kidney functions:}

Administration of tramadol at $30 \mathrm{mg} / \mathrm{kg}$ significantly increased creatinine, urea nitrogen and uric acid in serum when compared with the normal control and other groups. The present work discovered a highly significant decrease in serum creatinine, urea nitrogen and uric acid were recorded to high doses of barley grass and wheat grass $500 \mathrm{mg} / \mathrm{kg}$, as illustrated in (table 3). 
Egypt. J. of Nutrition and Health Vol. 15 No. 1 January (2020)

Table ( 3) :

Effects of Barley grass (BG) and Wheat grass (WG) powder on kidney functions parameters in serum of rats (mean $\pm S D$ ).

\begin{tabular}{|c|c|c|c|}
\hline Groups & Creatinine $(\mathrm{mg} / \mathrm{dl})$ & Urea nitrogen (mg/dl) & Uric acid $(\mathrm{mg} / \mathrm{dl})$ \\
\hline Normal control & $0.78 \pm 0.07^{d}$ & $15.3 \pm 2.50^{d}$ & $2.71 \pm 0.15^{c}$ \\
\hline Tramadol 30 mg/kg/d & $1.2 \pm 0.03^{a}$ & $38.6 \pm 2.79^{a}$ & $4.15 \pm 0.09^{a}$ \\
\hline Tramadol + BG(250mg/kg/d) & $0.91 \pm 0.04^{b}$ & $30.7 \pm 1.82^{b}$ & $3.25 \pm 0.11^{b}$ \\
\hline Tramadol + BG (500mg/kg/d) & $0.80 \pm 0.04^{\mathrm{cd}}$ & $25.6 \pm 1.40^{c}$ & $2.93 \pm 0.41^{b c}$ \\
\hline Tramadol + WG (250mg/Kg/d) & $0.88 \pm 0.04^{\mathrm{bc}}$ & $30.9 \pm 2.07^{b}$ & $3.29 \pm 0.12^{b}$ \\
\hline Tramadol + WG $(500 \mathrm{mg} / \mathrm{kg} / \mathrm{d})$ & $0.79 \pm 0.07^{\mathrm{cd}}$ & $23.1 \pm 2.37^{c}$ & $2.96 \pm 0.47^{\mathrm{bc}}$ \\
\hline
\end{tabular}

\section{Serum protein:}

The measured parameters serum total protein, albumin and globulin are summarized in (table 4). Results indicated that administration of tramadol at $30 \mathrm{mg} / \mathrm{kg}$ decreased the activity of total protein, albumin and globulin as compared to normal control. On the other aspect, barley grass and wheat grass $(500 \mathrm{mg} / \mathrm{kg})$ were significantly increased in these parameters as compared to tramadol group and other groups.

Table (4) :

Effects of Barley grass (BG) and Wheat grass (WG) powder on serum protein in rats (mean $\pm S D)$.

\begin{tabular}{l|c|c|c}
\hline Groups & Total protein $(\mathrm{g} / \mathrm{dl})$ & Albumin $(\mathrm{g} / \mathrm{dl})$ & Globulin $(\mathrm{g} / \mathrm{dl})$ \\
\hline Normal control & $5.27 \pm 0.37^{\mathrm{a}}$ & $3.55 \pm 1.21^{\mathrm{a}}$ & $1.72 \pm 0.48^{\mathrm{a}}$ \\
\hline Tramadol $30 \mathrm{mg} / \mathrm{kg} / \mathrm{d}$ & $2.25 \pm 0.21^{\mathrm{c}}$ & $1.54 \pm 0.21^{\mathrm{b}}$ & $0.71 \pm 0.21^{\mathrm{a}}$ \\
\hline Tramadol + BG $(250 \mathrm{mg} / \mathrm{kg} / \mathrm{d})$ & $3.79 \pm 0.68^{\mathrm{b}}$ & $2.51 \pm 1.10^{\mathrm{ab}}$ & $1.28 \pm 0.56^{\mathrm{bc}}$ \\
\hline Tramadol + BG $(500 \mathrm{mg} / \mathrm{kg} / \mathrm{d})$ & $4.45 \pm 1.13^{\mathrm{bc}}$ & $2.66 \pm 0.67^{\mathrm{ab}}$ & $1.79 \pm 0.50^{\mathrm{ab}}$ \\
\hline Tramadol + WG $(250 \mathrm{mg} / \mathrm{Kg} / \mathrm{d})$ & $3.91 \pm 0.36^{\mathrm{b}}$ & $2.84 \pm 0.09^{\mathrm{b}}$ & $1.07 \pm 0.75^{\mathrm{c}}$ \\
\hline Tramadol + WG $(500 \mathrm{mg} / \mathrm{kg} / \mathrm{d})$ & $4.71 \pm 0.35^{\mathrm{bc}}$ & $2.89 \pm 0.13^{\mathrm{ab}}$ & $1.82 \pm 0.16^{\mathrm{abc}}$ \\
\hline
\end{tabular}

Means in the same column with completely different letters are significantly different at $p<0.05$.

\section{Oxidative markers and antioxidants levels in serum:}

Results registered in Table (5) showed serum nitric oxides (NO), malondialdehyde (MDA), catalase (CAT) and glutathione peroxidase (GPX). The data revealed that, there were significant increase for NO and MDA and significant decrease for CAT and GPX for tramadol group as compared to normal control. Barley grass $(500 \mathrm{mg} / \mathrm{kg}$ ) followed by wheat grass $(500 \mathrm{mg} / \mathrm{kg}$ ) recorded significant decrease in serum NO, while barley grass at doses (500 and $250 \mathrm{mg} / \mathrm{kg}$ ) caused significant decrease in serum MDA followed by wheatgrass $(500 \mathrm{mg} / \mathrm{kg})$. In contrast barley grass $(500 \mathrm{mg} / \mathrm{kg})$ and wheat grass $(500 \mathrm{mg} / \mathrm{kg}$ ) revealed highly significant increase in serum CAT, GPX as compared to tramadol group and all grasses groups . 


\section{Hanan Salah Eldeen Eldamaty}

Table (5) :

Effects of Barley grass (BG) and Wheat grass (WG) powder on NO, MDA, CAT and GPX in serum of rats (mean $\pm \mathrm{SD}$ ).

\begin{tabular}{|c|c|c|c|c|}
\hline Groups & $\mathrm{NO}(\mathrm{nmol} / \mathrm{ml})$ & MDA (nmol/ml) & CAT $(\mathrm{ng} / \mathrm{ml})$ & GPX (ng/ml) \\
\hline Normal control & $43.88 \pm 0.88^{\mathrm{e}}$ & $46.50 \pm 3.50^{\mathrm{e}}$ & $53.50 \pm 3.50^{\mathrm{a}}$ & $39.00 \pm 2.00^{\mathrm{a}}$ \\
\hline Tramadol $30 \mathrm{mg} / \mathrm{kg} / \mathrm{d}$ & $92.50 \pm 2.50^{\mathrm{a}}$ & $117.50 \pm 2.50^{\mathrm{a}}$ & $30.00 \pm 2.00^{d}$ & $12.50 \pm 1.50^{\mathrm{d}}$ \\
\hline Tramadol + BG(250mg/kg/d) & $73.75 \pm 2.75^{b}$ & $58.00 \pm 2.00^{d}$ & $37.50 \pm 2.50^{c}$ & $22.50 \pm 2.50^{\mathrm{c}}$ \\
\hline Tramadol + BG $(500 \mathrm{mg} / \mathrm{kg} / \mathrm{d})$ & $51.25 \pm 1.25^{d}$ & $48.50 \pm 1.50^{\mathrm{e}}$ & $52.00 \pm 3.00^{\mathrm{a}}$ & $32.50 \pm 2.50^{b}$ \\
\hline Tramadol + WG $(250 \mathrm{mg} / \mathrm{Kg} / \mathrm{d})$ & $76.50 \pm 6.50^{6}$ & $83.00 \pm 3.00^{b}$ & $34.00 \pm 1.00^{\text {cd }}$ & $20.00 \pm 2.00^{c}$ \\
\hline Tramadol + WG $(500 \mathrm{mg} / \mathrm{kg} / \mathrm{d})$ & $61.25 \pm 0.75^{c}$ & $74.50 \pm 2.50^{c}$ & $43.50 \pm 1.50^{b}$ & $29.00 \pm 1.00^{6}$ \\
\hline
\end{tabular}

Means in the same column with completely different letters are significantly different at $\mathrm{p}<0.05$.

\section{Oxidative markers and antioxidants levels in kidneys tissues:}

Table (6) showed a highly significant increase in nitric oxide (NO), malondialdehyde (MDA) in kidney tissues and highly significant decrease in catalase (CAT) and reduced glutathione (GSH) in kidney tissues of tramadol group as compared to normal control. Administration of barley grass and wheat grass at dose $(500 \mathrm{mg} / \mathrm{kg}$ ) revealed a significant decrease in NO, MDA. In the same time they caused significant increase in CAT, GSH of kidney tissues.

Table ( 6 ) :

Effects of Barley grass (BG) and Wheat grass (WG) powder on NO, MDA, CAT and GSH in kidney tissues of rats (mean $\pm S D$ ).

\begin{tabular}{l|c|c|c|c}
\hline Groups & NO $(\mathrm{nmol} / \mathrm{mg})$ & MDA $(\mathrm{nmol} / \mathrm{mg})$ & CAT $(\mathrm{ng} / \mathrm{mg})$ & GSH $(\mathrm{ng} / \mathrm{mg})$ \\
\hline Normal control & $32.38 \pm 0.6^{\mathrm{d}}$ & $59.83 \pm 0.8^{\mathrm{d}}$ & $61.0 \pm 2.0^{\mathrm{a}}$ & $9.88 \pm 1.1^{\mathrm{a}}$ \\
\hline Tramadol 30 mg/kg/d & $94.25 \pm 0.8^{\mathrm{a}}$ & $162.5 \pm 12.5^{\mathrm{a}}$ & $14.8 \pm 0.8^{\mathrm{d}}$ & $1.33 \pm 0.18^{\mathrm{d}}$ \\
\hline Tramadol + BG $(250 \mathrm{mg} / \mathrm{kg} / \mathrm{d})$ & $70.50 \pm 2.3^{\mathrm{b}}$ & $118 \pm 7.0^{\mathrm{b}}$ & $16.6 \pm 0.6^{\mathrm{d}}$ & $3.28 \pm 0.13^{\mathrm{c}}$ \\
\hline Tramadol + BG $(500 \mathrm{mg} / \mathrm{kg} / \mathrm{d})$ & $50.00 \pm 3.0^{\mathrm{c}}$ & $79 \pm 7.0^{\mathrm{c}}$ & $41.0 \pm 1.0^{\mathrm{c}}$ & $5.44 \pm 0.68^{\mathrm{b}}$ \\
\hline Tramadol + WG $(250 \mathrm{mg} / \mathrm{Kg} / \mathrm{d})$ & $66.00 \pm 7.0^{\mathrm{b}}$ & $82.3 \pm 6.8^{\mathrm{c}}$ & $38.4 \pm 0.4^{\mathrm{c}}$ & $4.80 \pm 0.36^{\mathrm{bc}}$ \\
\hline Tramadol + WG $(500 \mathrm{mg} / \mathrm{kg} / \mathrm{d})$ & $42.67 \pm 3.2^{\mathrm{c}}$ & $63.3 \pm 3.8^{\mathrm{d}}$ & $51.8 \pm 5.8^{\mathrm{b}}$ & $6.48 \pm 1.21^{\mathrm{b}}$ \\
\hline
\end{tabular}

Means in the same column with completely different letters are significantly different at $p<0.05$.

\section{Discussion}

Tramadol and its metabolites are emitted by kidneys, therefore, the kidney is considered to be the main objective organ for tramadol toxicity (Janssen-Ortho, 2005). Tramadol HCL caused nephrotoxic effects by affecting renal function and increasing oxidative stress (Ali et al., 2020).

The present study showed decrease of feed intake (FI), body weight gain \% (BWG) and feed efficiency ratio (FER) in tramadol group which is in accordance with studies of Oka et al., (2015) who reported that administration of tramadol has inhibitory effects on the appetite centers of the hypothalamus which may explain the low food intake in these groups. Also these results were in harmony with Elbadrawy and Elkewawy, (2019) who reported that there were significant decreases in weight gain, feed intake and feed efficiency ratio in tramadol group. They explained that tramadol led to some intestinal disturbances such vomiting, nausea and constipation with change in appetite Abd El-Mottaleb et al., (2019) cleared that there was decrease in body weight of rats given tramado $30 \mathrm{mg} / \mathrm{kg} /$ day for three months. In contrast Ali et al., $(2020)^{\mathrm{b}}$ showed that receiving tramadol at 3 doses $25 \mathrm{mg} / \mathrm{kg}, 50 \mathrm{mg} / \mathrm{kg}$ and $75 \mathrm{mg} / \mathrm{kg}$ of body weight did not alter feed intake but reduced body weight in rats. 


\section{Egypt. J. of Nutrition and Health Vol. 15 No. 1 January (2020)}

In this study, all grasses groups increased feed intake as compared to tramadol group, while barley and wheat grasses at dose $500 \mathrm{mg} / \mathrm{kg}$ reduced body weight gain on the other hand, wheat grass group $250 \mathrm{mg} / \mathrm{kg}$ improved FER. Jorige and Akula (2015) reported that regular consumption of the wheat grass can develop the gastrointestinal system. wheatgrass juice reduce body weight as it contains selenium which improved function of the thyroid gland and contain potassium which aspects in coming off of water weight. So that, managing body weight. Also, wheat grass blocks the stomach, thus suppressing the appetite (Husain et al., 2017). Ghoniem et al., (2018) cleared that administration fresh wheat grass Juice to rats received high fat diet reduced body weight gain. According barley grass powder Ikeguchi et al., (2014) cleared that adding barley leaf powder in the diet increased the fecal weight as it contain water-soluble dietary fiber and stimulating gastrointestinal tract by $\mathrm{pH}$ lowering .Daotong et al ., (2018) reported that barley leaf (BL) contains abundant plant fibers, which are important substrates for the metabolism. The barley grass is a health drink in many parts of India. It suppresses obesity and cholesterol levels (Thatiparthi et al., 2019). Oral administration of polysaccharides isolated from barley leaf improved the decrease of body weight (Han et al., 2020).

Relative organs weight estimations are an important part of the toxicological evaluation of chemical ingredients. In the present study, there were no significant changes of relative kidney weights in tramadol group and the other groups, This statement is consistent with Adikwu and Nelson, (2018) when they reported that absolute and relative kidney weights were not significantly altered in the tramadol treated rats in comparison to control. Also, the finding is in harmony with Obembe and Olatoke, (2019) they stated that admiration tramadol $(50 \mathrm{mg} / \mathrm{kg})$ of male wistar rats had no significant effect on relative kidney weight .

Regarding grasses Foda, (2010) reported that adding young green barley leaves powder might improve kidney weight and kidneys functions . Lakshmi et al., (2015) showed that consumption of wheat grass extract orally (200 and $400 \mathrm{mg} / \mathrm{kg}$ ) by rats for 20 following days before oral receiving of sodium arsenite significantly preserved kidney weights of experimental rats towards normal after arsenic exposure.

Kidney functions parameters in serum of rats are important tools used for the evaluations of the toxicological profile of tramadol drug. In the present study, tramadol group recorded the highest increase in creatinine, blood urea nitrogen and uric acid. These results came in accordance with the documented data of Elwy and Tabl, (2014) who revealed that, administration of tramadol for one month induced significant increase in serum urea and creatinine concentrations as compared to control rats. Aldalou et al., (2014) explained the increases in both urea and creatinine in rats received tramadol due to kidney damage, arise in blood damaging of nephrons function and weakened kidney function. Also, Hussein et al., (2017) showed that, tramadol administration induced kidney dysfunction, this explained through increasing urea and creatinine in serum of rats induced tramadol. Muslim, (2018) cleared that mice administrated tramadol had an increase in blood urea and serum creatinine levels as compared to control group. These results are consistent with Haytham et al., ( 2020) who approved that elevation levels of blood urea and serum creatinine after tramadol administration in rats.

Sara et al., (2016) found that treatment with barley extract against DMN-induced kidney toxicity for 4 weeks improved kidney functions as indicated by reduction of serum creatinine, urea and uric acid levels. Our results data are harmony with Comba et al., (2017) who stated that administration barley grass orally ( $250 \mathrm{mg} / \mathrm{kg} /$ day ) for 4 weeks decreased levels of serum urea , creatinine and protective to renal glomerular and tubular damage. Barley grass powder has antioxidant 


\section{Hanan Salah Eldeen Eldamaty}

effect and rich in phytochemical compunds, such as flavonoids, saponarin, , chlorophyll, vitamins $(A$, B1, C, and E), dietary fiber, polyphenols. Also, it eliminated toxins from cells (Zeng et al., 2018). Neethu et al., (2016) reported that consumption of wheat grass juice regularly cured the complications which resulted from increased uric acid in blood also cured inflammation of the urinary bladder, and inflammation of the kidneys. Hesham et al., (2020) showed that wheat grass juice improved kidney function parameters (Urea, Createnine and uric acid) as it has vitamin C and phenolic compounds which caused detoxification for liver and kidneys organs and filtration the blood from toxins.

In the current study total protein, albumin and globulin were significantly decreased after tramadol administration. These results are in line with Khalaf , (2017) who reported that tramadol administration decreased the levels of total protein, albumin and globulin due to oxidative stress and hepatic injury. Adikwu and Nelson, (2018) determined the serum of total protein and albumin of rats which received tramadol and they found a decrease in the levels of these parameters. This is attributed to kidney damage and nephrotoxicity. Tramadol administration increased oxidative stress, hepatotoxicity and nephrotoxicity. Although, it is stated to be active in pain controlling, its toxicity should be preserved in notice ( Owoade et al., 2019).

In the present finding, administration barley grass and wheat grass $(500 \mathrm{mg} / \mathrm{kg}$ ) increased total protein , albumin and globulin in serum of rats. Foda, (2010) cleared that addition of young green barley leaves powder improved the liver and kidneys functions in hypercholesterolemic rats due to antioxidant capacity. Increased protein may be due to phenols existing in the wheatgrass might have successfully prohibited the cell membrane injury (Datta et al., 2012). Consumption Wheat grass extract increased the total protein near normal (Lakshmi et al., 2015). Using Wheat grass as nourishment increased protein and albumin. It may have an advantageous effects on the liver of rats (Al Jumaily et al., 2019).

The present work detected a highly significant increase in serum of NO, MDA levels and significant reduction in serum of CAT and GPX levels in tramadol group as compared to normal control. The current results confirmed the results of an earlier study directed by Ahmed and Kurkar, (2014) who suggested that tramadol caused lipid peroxidation and increased MDA levels. The major reduction in GSH activity can be described by its consumption through the purification of reactive oxygen metabolites (Hamza and Al-Harbi, 2014). Hindawy et al., (2019); Nazifi et al., (2019); and Omar et al., (2019) confirmed the present results about administration tramadol increased serum MDA and NO due to oxidative stress, increasing the lipid peroxidation and increasing the generation of free radicals.

Our results indicated that barley grass and wheat grass $(500 \mathrm{mg} / \mathrm{kg})$ recorded significant decrease in serum of NO, MDA. Also they revealed significant increase in serum CAT, GPX as compared to tramadol group and all grasses groups. Barley grass is rich in antioxidants which overturn lipid peroxidation, such as polyphenols, saponarin, lutonarin, superoxide dismutase (SOD), Se, chlorophyll, vitamins ( pro vitamin A, C and E) and flavonoids (Zeng et al., 2018). Thatiparthi et al., (2019) showed that barley grass juice (Hordeum vulgare L.) has potent antioxidant action. barley sprouts juice inhibited the increase of malondialdehyde level and the reduction of catalase activities (Mohamed et al., 2019). Barley grass possesses antioxidant properties (Deng et al., 2020). Wheatgrass has many antioxidant compounds as Selenium, pro vitamin A, C, E, Carotene, transhydrogenase and superoxide dismutase (SOD) cytochrome oxidase (Padalia et al., 2010). Wheat grass contains great amount of antioxidants, thus it can be used as an antioxidant phytomedicine against oxidative stress produced by chemotherapeutic drugs (Sachin et al., 2013). 


\section{Egypt. J. of Nutrition and Health Vol. 15 No. 1 January (2020)}

Durairaj et al., (2014) cleared that administration of wheatgrass to male albino rats returned levels of antioxidants to normal as superoxide dismutase, catalase, glutathione peroxidase, reduced glutathione, vitamin $\mathrm{E}$, and vitamin $\mathrm{C}$, which had decreased resulting from alcohol which induced oxidative stress.

The obtained results of oxidative stress markers and antioxidant enzymes in kidneys tissues supported this results of oxidative stress markers and antioxidant enzymes in serum of rats we found that increase in MDA, NO levels and decrease in CAT, GSH in kidneys tissues of rats received tramadol. These data are reliable with Elkhateeb et al., (2015) who confirmed that tramadol administration $30 \mathrm{mg} / \mathrm{kg} /$ day increased the MDA level in kidneys tissues since it is sensitive biomarker of lipid peroxidation and decreased the GPX level as it contain a transition metal as cofactor. The contact of tramadol with metals of these enzymes may reserve in the activities of these enzymes. In addition, Awadalla, and Salah-Eldin (2015) documented that tramadol usage induced oxidative stress through increasing MDA level, decreasing the activities of GSH, SOD and CAT enzymes in both liver and kidney tissues. Owoade et al., (2019) confirmed that tramadol administration increased the risk of oxidative stress, nephrotoxicity. Tramadol HCL caused hepatic and renal oxidative damage by increasing lipid peroxidation (MDA) and decreasing the activity of antioxidant enzymes (GSH ,CAT and SOD) (Ali et al., 2020).

The present study found that administration barley grass and wheat grass $(500 \mathrm{mg} / \mathrm{kg})$ improved antioxidant enzymes in kidneys tissues of rats. Barley grass juice rich in natural antioxidants which prevented from free radicals in goat liver model (Jhansyrani et al., 2019). Zeng et al., (2020) demonstrated that barley grass has antioxidant components as flavonoids, SOD, vitamins combat chronic diseases. Wheat grass has protective effect against the oxidative stress in diabetes rats either by preventing generation free radical or by stimulating endogenous antioxidant protection or both in body tissues (Shakya et al., 2012). Wheat grass contains both of enzymatic and non-enzymatic antioxidants so, it reduced the oxidative stress (Sachin et al., 2013). Rats that received wheat grass showed the normal glomerulus and tubular construction (Lakshmi et al., 2014).Wheat grass extract obviously normalized antioxidant enzymes in liver and kidney tissues by detoxification of body cells from free radical (Lakshmi et al., 2015). 


\section{References}

Abd El-Mottaleb1, H.; Mahmoud, S.; Hassan,A.; Tealeb, A. and Almorsy, G. (2019):

Effects of Chronic Use of Tramadol on Uterus and Ovary of Albino Rats. The Egyptian Journal of Hospital Medicine, 76 (1): 3184-3190.

Abed, K.A.K.; Yaqoob, K.; Abdoh, A.O.O.; Mohammed, S.M.; Pankaj, T.; Hakeem, S.M.A. and Mamoon, H.S. (2017):

Investigation of Antigenotoxic Potential of Wheatgrass (Triticumaestivum) Powder on Cyclophosphamide Induced Genotoxicity and Oxidative Stress in Mice. Austin Journal of Pharmacology and Therapeutics, 5 (3): 1-6.

Adikwu, E. and Bonsome, B. (2017):

Renal implication of nevirapine use in juvenile albino rats. Journal of Interdisciplinary Histopathology, 5(2): 43- 47.

Adikwu,E. and Nelson, E. (2018):

Assessments of kidney function and morphology of tramadol diclofenac treated albino rats. Advancements in Life Sciences - International Quarterly Journal of Biological Sciences, 5 (3): 104:112.

Aebi, H. (1974):

Methods of enzymatic analysis (Bergmeyer H. U., ed), 2nd Ed., Verlag Chemie, Weinheim, 2: 673-78.

Ahmed, A.I.; El-Dawy, K.; Fawzy,M.M.; Abdallah, H.N. and Elmesslamy, W.O. (2018):

Retrospective review of tramadol abuse. Slov Vet Res., 55 (20): 471-83.

Ahmadvand, H.; Dehnoo,G. M.; Cheraghi, R.; Rasoulian, B.; Ezatpour, B. and Azadpour, M. (2014):

Amelioration of altered serum, liver, and kidney antioxidant enzymes activities by sodium selenite in alloxan-induced diabetic rats. Rep Biochem Mol Biol.,3:14-20.

Ahmed, M.A. and Kurkar, A. (2014):

Effects of opioid (tramadol) treatment on testicular functions in adult male rats: the role of nitric oxide and oxidative stress. Clin Exp Pharmacol Physiol., 41:317-323.

Aldalou, A.R.; Abdel-Aziz, I. and Shahwan, O. (2014):

Impact of giving sildenafil (Viagra) Tramadol (Tramal) combination on the blood of domestic rabbits. J Sci., 4(3): 162-169.

Al Jumaily,A.; Aldulaimi, A. and Al Jumaily, M.H. (2019):

Effect of wheatgrass and spirulina as nutrition supplement on some histological and biochemical parameters in lactating female rats. Plant Archives, 19 (2): 4274- 4278. 


\section{Egypt. J. of Nutrition and Health Vol. 15 No. 1 January (2020)}

Ali , H.; Afifi , M.; Saber , T.; Makki, A.; Keshta ,A.; Baeshen, M. and Al-Farga ,A. (2020) Neurotoxic, Hepatotoxic and Nephrotoxic Effects of Tramadol Administration in Rats. Journal of Molecular Neuroscience, DOI: 10.1007/s12031-020-01592-x.

Ali, T.; Rafiq,M.; Mubarik,M.; Zahoor,K.; Asad,F.; Yaqoob,S.; Ahmad,S. and Qamar, S. (2020) Genotoxicity and repair capability of Mus musculus DNA following the oral exposure to Tramadol. Saudi Journal of Biological Sciences ,27:12-17.

Awadalla, E. and Salah-Eldin, A.(2015):

Histopathological and Molecular Studies on Tramadol Mediated Hepato-Renal Toxicity in Rats. Journal of Pharmacy and Biological Sciences, 10 (6) : 90-102.

Barbosa, J.; Faria, J.; Leal, S.; Afonso, L.P.; Lobo, J.; Queiros, O.; Moreira, R.; Carvalho, F.and Dinis-Oliveira, R.J. (2017):

Acute administration of tramadol and tapentadol at effective analgesic and maximum tolerated doses causes hepato- and nephrotoxic effects in Wistar rats. Toxicology, 389:118-129.

Bowers, L. and Wong, E. (1980):

Kinetic serum creatinine assays II. A critical evaluation and review. Clin Chem., 26: 555-561.

Chapman, D.G.; Castilla, R. and Cambell, A.J. (1959):

Evaluation of protein in food. In Method for the Documentation of protein Efficiency Ratio. Can. J. Biochem. Physiol., 37; 679-686.

Chauhan, M. (2014):

A pilot study on wheat grass juice for its phytochemical, nutritional and therapeutic potential on chronic diseases. Int J Chem Stud., 2: 27-34.

Comba, B.; Mis, L.; Uslu, S. and Comba, A.(2017):

The effect of barley grass on antioxidant capacity and DNA damage in rat with renal failure. Fresenius Environmental Bulletin, 26 (10): 6135- 6140

Cosola, C.; Angelis, M. and Rocchetti, M. T.(2017):

Beta-glucans supplementation associates with reduction in p-cresyl sulfate levels and improved endothelial vascular reactivity in healthy individuals. PLoS One., 12(1): e0169635, 2017.

Daotong, L.; Wang,P.; Wang, P.; Hu,X. and Chen, F. (2018):

Gut microbiota promotes production of aromatic metabolites through degradation of barley leaf fiber. Journal of Nutritional Biochemistry, $58: 49-58$.

Datta, G.; Basu, A.; Sen, and Nath, P. (2012):

Role of a-tocopherol, B-carotene and ascorbic acid against alcohol induced hepatotoxicity: A comparative analysis. J. Pharm. Res., 5: 2485-2488.

Deng, L.; Feng, G.; Gao, Y.; Shen, Y.; Li , H.; Gu, Y. and Luan, H. (2020): Phytochemical Constituents and Antioxidant Enzyme Activity Profiles of Different Barley (Hordeum Vulgare L.) Cultivars at Different Developmental Stages. Agronomy, 10 (37): 1-11. 


\section{Hanan Salah Eldeen Eldamaty}

Doumas, B.T.; Watson, W.A. and Biggs, H.G. (1977):

Albumin standards and the measurement of serum albumin with bromocresol green. Clin Chim Acta., 31: 87-96.

Durairaj, V.; Shakya, G. and Rajagopalan, R.(2014):

Hepatoprotective role of wheatgrass on alcohol and $\triangle$ PUFA-induced oxidative stress in rats. Journal of Dietary supplement, 12(2): DOI: 10.3109/19390211.2014.902002.

Elbadrawy, E. and Elkewawy, H.(2019):

Alleviation of Tramadol-Induced Liver Toxicity in Experimental Rats by Using Kiwifruit, Turmeric Extract or Their Combination. J. of Food and Dairy Sci., Mansoura Univ., 10 (10): $381-387$.

Elkhateeb, S.; El Khishina, I.; Megaheda, O. and Mazenb, F. (2015):

Effect of Nigella sativa Linn oil on tramadol-induced hepato-and nephrotoxicity in adult male albino rats. Toxicology Reports, 2 : 512-519.

Elwy, A. and Tabl, G. ( 2014):

Effects of Chronic Usage of Tramadol, Acetaminophen and Tramacet on Some Biochemical and Immunological Changes in Male Rats. J Drug Res Egypt., 35(1): 63-71.

Foda, M. (2010):

Biochemical studies on antioxidants extracted from young green barley leaves. Master of science in Agricultre science (Biochemistry). Department of Biochemistry Faculty of Agriculture Benha Universty.

Fossati, P.; Prencipe, L. and Berti, G. A. (1980):

New direct colorimetric procedure for uric acid in serum and urine. Clinical Chemistry, 26(2):227-231.

George, W. Sneddecor and William, G. (1989):

Cochran [book review]. Statistical methods. Eighth Edition, lowa State University Press.

Ghoniem, G.; Abou- Raya, M.; Abd EL Hameed, A. and Elrayes, N. (2018):

Influence of Using Fresh Wheat Grass Juice and its Blends on Hypercholesterolemic Rats. J. Food and Dairy Sci., 3rd Mansoura International Food Congress, 137 - 145.

Goth, L.; Nemeth, H. and Meszaros, I.(1984):

Clinical study of the determination of serum catalase enzyme activity. Hung Sci Instr., 57:7-12.

Green, L. C.; Wagner, D. A.; Glogowski, J.; Skipper, P. L.; Wishnok, J. S. and Tannenbaum, S. R.(1982):

Analysis of nitrate, nitrite, and [15N]nitrate in biological fluids. Analytical Biochemistry, 126(1): 131-138. 


\section{Egypt. J. of Nutrition and Health Vol. 15 No. 1 January (2020)}

Hamza, R.Z. and Al-Harbi, M.S. (2014):

Monosodium glutamate induced testicular toxicity and the possible ameliorative role of vitamin E or selenium in male rats. Toxicol Rep.,22(1):1037-1045.

Han, H.; Shin, J.; Song, Y.; Rhee, Y.; Choc, C.; Ryu, J.; Inn, K.; Hong, H. and Lee, K.(2020): Immunostimulatory effects of polysaccharides isolated from young barley leaves (Hordeum vulgare L.) with dual activation of Th1 and Th2 in splenic T cells and cyclophosphamideinduced immunosuppressed mice. International Journal of Biological Macromolecules,147: 954-964.

Haytham, A. A.; Taghred, M.A.; Arwa, M.S.; Makki, A.; Keshta, T.; Baeshen, M. and Al-Farga, A. (2020): Neurotoxic, Hepatotoxic and Nephrotoxic Effects of Tramadol Administration in Rats. Journal of Molecular Neuroscience, DOI: 10.1007/s12031-020-01592-x.

Hesham, A.; Eissa, Mohamed, S.; Ahmed, M. and Hussein, S.(2020):

Nutritional value and impact of wheatgrass juice (Green Blood Therapy) on increasing fertility in male albino rats. Bulletin of the National Research Centre, 44 (30): https://doi.org/10.1186/s42269-020-0272-x.

Hindawy, R. F.; Ali, N.A. and Hendawy, F.F. (2019):

Ameliorative effect of Aloe Vera gel on tramadol reproductive toxicity in adult albino rats. Zagazig J. Forensic Med.\& Toxicology, 17 (2): 71 - 83.

Hosoya, N. (1980):

Determination of feed efficiency ratio . Cited in Hosoya, $\mathrm{N}$.; Inami , S. and Goto , S., eds. Nutrition Experiments Using Small Animals. Daiichi Shuppan, Tokyo, Japanese, pp:71.

Husain , N.; Trak, T. and Chauhan, D. (2017):

wheat grass :herbal remedy for health and beauty. Flora and Fauna, 23: 143-148.

Hussein , S.; Abdel Aal,S, and Ismail, H. (2017):

Effect of tramadol drug on some biochemical and immunological parameters in albino male rats; evaluation of possible reversal following its withdrawal. Benha veterinary medical journal, 33 (2): 418-429.

Ikeguchi,M.; Tsubata,M.; Takano,A.; Kamiya,T.; Takagaki,K.; Ito, H.; Sugawa-Katayama,Y. and Tsuji, H. (2014) :

Effects of Young Barley Leaf Powder on Gastrointestinal Functions in Rats and Its EfficacyRelated Physicochemical Properties. Evidence-Based Complementary and Alternative Medicine, 2014, :1-7.

Jain, G. and Argal, A. (2014):

Hepatoprotective potential of young leaves of Triticum aestivum Linn. against CCl4 induced hepatotoxicity. Int J Pharm Sci \& Res., 5(11): 4751-4755. 


\section{Hanan Salah Eldeen Eldamaty}

Janssen-Ortho, Inc. 2005:

Tramacet: A Product Monograph; pp. 1-36. www.janssen-ortho.com.

Jhansyrani, T.; Sujatha, D.; Rupasree, P.; Bharathi, K. and Kvsrg, P. (2019):

In-vitro antioxidant potential of selected nutraceuticals. International Journal of Pharmaceutical Sciences and Research,10(3): 1426-1432.

Jorige, A. and Akula, A. (2015):

Neuroprotective Role of Wheatgrass Powder in Experimental Diabetic Neuropathy via Modulating Oxidative Stress Markers in Rat Sciatic Nerves. American Journal of Phytomedicine and Clinical Therapeutics, 3 (7):529-540.

Kaplan, A. (1984):

Urea. Clin Chem., 1257- 1260 and 437 and 418.

Khalaf, A.N. (2017):

Silymarin extract modulates toxicity, injury, oxidative stress and PCNA alternations induced by tramadol in rat liver. Journal of Bioscience and Applied Research ,3 (1): 28-35.

Lakshmi, B.; Sudhakar, M.; Sudha, F. and Gopa, M. (2015):

Ameliorative effect of Triticum aestivum Linn against experimentally induced arsenic toxicity in male albino rats. Scholars Research Library Der Pharmacia Lettre, 7 (1):202-211.

Lakshmi, B.V.S.; Sudhakar, M. and Nireesha, G. (2014):

Modification of mercury-induced biochemical alterations by Triticum Aestivum Linn in rats. Indian J Physiol Pharmacol., 58(4) : 423-436.

Malla, S.; Mourya, M.K.; Halder,D.; Gomroki, F. and Mohammed, H. (2014):

Healing effects of Wheat Grass (Triticum aestivum L) extracts on RBC Membrane Damage. American Journal of Life Sciences, 2 (6-1): 22-27.

Maral, J.; Puget, K. and Michelson, A.M. (1977):

Comparative study of superoxide dismutase, catalase and glutathione peroxidase levels in erythrocytes of different animals. Biochem. Biophys. Res. Commun., 77(4): 1525-1535.

Mohamed,R.S.; Diaa , M.A.; Salah, H.S.; Ahmed H.Z.; Ihab, A.S.; Abdel Razik, F.H. and Ahmed, A.M.(2019):

Hypoglycemic, hypolipidemic and antioxidant effects of green sprouts juice and functional dairy micronutrients against streptozotocin-induced oxidative stress and diabetes in rats. Heliyon, 5 (2): 01197.

Moshage, H.; Kok, B.; Huizenga, J.R. and Jansen, P.L.(1995):

Nitrite and nitrate determinations in plasma: a critical evaluation. Clin Chem., 41(6 Pt 1):892-6.

Murray, R. L. and Kaplan, A. (1984):

Creatinine. Clin Chem., 1261- 1266 and 418. 


\section{Egypt. J. of Nutrition and Health Vol. 15 No. 1 January (2020)}

Muslim, Z. (2018):

The Biochemical and Histological Effects of Tramadol on Liver and Kidney of Albino Mice. ThiQar Medical Journal, 15 (1): 43:57.

Nazifi, S.; Tabrizi , A.S.; Mohammadi, S.; Erjaee, H. and Mirzaie, A. (2019):

The effect of tramadol and meloxicam, alone and in combination on oxidative stress status in dogs. Comparative Clinical Pathology, 28(4): 1055-1060.

Neethu, S.; Kumar, Murali,M.; .Nair, A. M. and Nair, A.S. (2016):

Green Blood Therapy of Wheat Grass - Nature's Finest Medicine'- A Literature Review. IOSR Journal of Pharmacy and Biological Sciences, 11 (2): 57-64.

Obembe, O. and Olatoke, T. (2019):

Reproductive and biochemical parameters of tramadol and vitamin E in acutely treated male Wistar rats. Afr. J. Med. Med. Sci., 48: 243-249.

Oka, V.; Udefa,A.; Nna, V. and Owu, D.( 2015):

Sildenafil Citrate and Tramadol Administered Separately and in Combination Affects Basal Metabolic Rate, Triiodothyronine (T3) and Cortisol Levels in Albino Wistar Rats.

Trends in Medical Research, 10: 51-62.

Omar, M.E. Abdel-Salam, Youness, E. R.; Mohammed, N. A.; Abd El-Moneim, O.M. and Shaffie, N. (2019):

Citicoline Protects against Tramadol-Induced Oxidative Stress and Organ Damage. Reactive Oxygen Species, 7 (20): 106- 120.

Owoade, A. O.; Adetutu, A. and Olorunnisola, O.S.(2019):

Hematological and Biochemical Changes in Blood, Liver and Kidney Tissues under the Effect of Tramadol Treatment. Journal of Alcoholism \& Drug Dependence, 7(5): 1-7.

Padalia, S.; Drabu, S.; Raheja, I. and Gupta, A. (2010):

Multitude potential of Wheat grass Juice (Green Blood): An overview. Chron of Young Sci., 1 (2): 23-28.

Patterson, E. (2018):

Tramadol Facts, History, and Statistics [Accessed 26thMay, 2017](Available from:) http://drugabuse.com/library/tramadol-history-and-statistics/Google Scholar.

Pinho, S.; Oliveira, A.; Costa, I.; Gouveia, C.A.; Carvalho, F.; Moreira, R.F. and Dinis-Oliveira, R.J. (2013):

Simultaneous quantification of tramadol and O-desmethyltramadol in hair samples by gas chromatography- electron impact/mass spectrometry. Biomed Chromatogr ., 27:1003-1011.

Placer, Z.A.; Cushman, L.L. and Johnson, B.C. (1966):

Estimation of product of lipid peroxidation (Malonyl Dialdehyde) in biochemical systems. Anal. Biochem., 16: 359-364. 


\section{Hanan Salah Eldeen Eldamaty}

\section{Ruiz-Larrea, M.B.; Leal, A.M.; Liza, M.; Lacort, M. and Groot, H.(1994):}

Antioxidant effects of estradiol and 2-hydroxyestradiol on iron-induced lipid peroxidation of rat liver microsomes. Steroids, 59(6):383-388.

Sachin, S.; Kumar, S.V.; Archana, S. and Shrivastav B. R.(2013):

Therapeutic of potential of wheatgrass (Tritium Aestivum) against oxidative stress by platinum containing drugs during cancer chemotherapy: A future prospective. International Ayurvedic Medical Journal, 1 (5): 1 - 5.

Sara, B. A.; Abozalam, Abeer, A.; Salama, A.; Mahmoud, S.; Arbid,S.; Afaf, A.; Shoka, A.; Hekma, A. and Abd El-Latif. (2016):

Effect of Barley, Green Tea and Doxorubicin against N-dimethylnitrosamine Induced Hepatorenal Toxicity in Rats. Current Science International, 05 (4) : 386-399.

Sareen, M.; Baghla, P.; Dhaka, P.; Mathur, E.; Sobti, P. and Khajuria, S. (2014):

Wheat grass-a wonder herb. Syst Rev Pharm., 5(1):4.

Shakya,G.; Goud,C.; Pajaniradje, S. and Rajagopalan, R. (2012):

Protective role of wheatgrass on oxidative stress in streptozotocin induced type 2 diabetic rats. International Journal of Pharmacy and Pharmaceutical Sciences, 4 (3): 415-423.

Thatiparthi, J.; Dodoala, S.; Koganti, B. and Prasad,K. (2019):

Barley grass juice (Hordeum vulgare L.) inhibits obesity and improves lipid profile in high fat diet-induced rat model. Journal of Ethnopharmacology, 238 : 111843. DOI: 10.1016/j.jep.2019.111843.

Zeng , Y.; Pu , X.; Yang , J.; Du, J.; Yang, X.; Li, X.; Li, L.; Zhou, Y. and Yang, T. (2018):

Preventive and Therapeutic Role of Functional Ingredients of Barley Grass for Chronic Diseases in Human Beings.Oxidative Medicine and Cellular Longevity, 2018, 1-15. https://doi.org/10.1155/2018/3232080.

Zeng ,Y.; Pu ,X.; Du,J.; Yang,X.; Li,X.; (2020):

Molecular Mechanism of Functional Ingredients in Barley to Combat Human Chronic Diseases. Oxidative Medicine and Cellular Longevity, 2020(6373):1-26 https://doi.org/10.1155/2020/3836172. 
Egypt. J. of Nutrition and Health Vol. 15 No. 1 January (2020)

\author{
التأثيرات الوقائية لحشائش الشعير والقمح على تشمم الكلى وبعض المؤشرات البيو \\ كيميائية التي يسببها الترامادول في الجرذان
}

\title{
حنان صلاح الدين الدماطى
}

مدرس التغذية وعلوم الأطعمة ، قسم التغذية وعلوم الأطعمة ، كلية الاقتصاد المنزلي ، جامعة الأزهر ، مصر

\author{
المستخلص العربى
}

\begin{abstract}
أجريت هذه الدراسة الحالية لتقييم الآثار الوقائية لحشائش الثعير والقمح ضد تسمم الكلى الذى يسبيه الترمادول ، والتئيرات

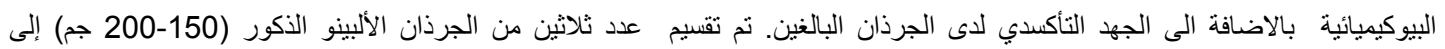

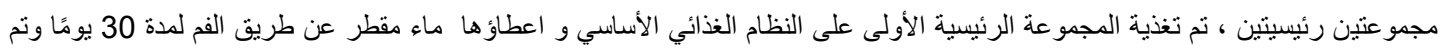

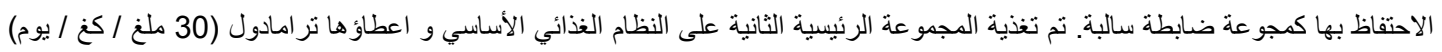

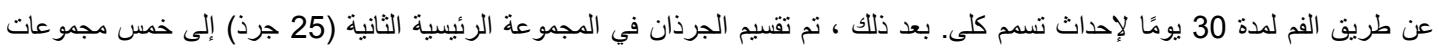

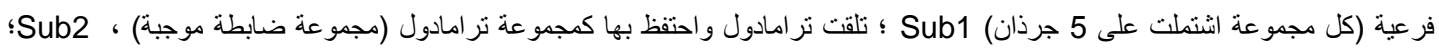

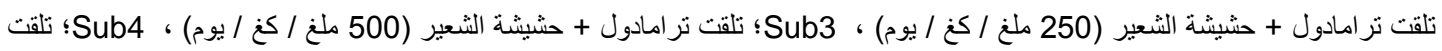

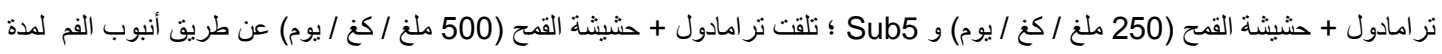

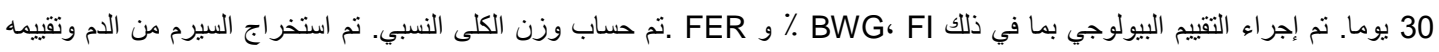

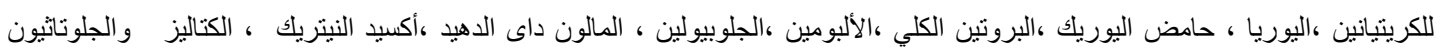

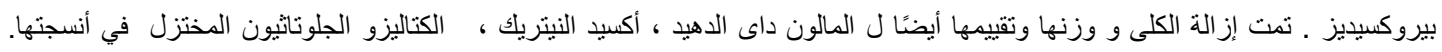

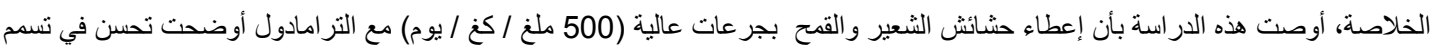

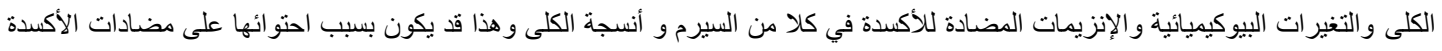

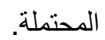
الكلمات المفتاحية: تسم الكلي، مؤشرات السيرم البيو كيميائية ، إنزيمات مضادات الأكسدة للسيرم ، إنزيمات مضادات للأكسدة لأنسجة الكلى، حشيشة الثعير ، حشيشة القمح.
\end{abstract}

